\begin{tabular}{|c|c|c|}
\hline \multirow{2}{*}{$\begin{array}{r}\text { Case Reports in } \\
\text { Gastroenterology }\end{array}$} & \multicolumn{2}{|c|}{ Case Rep Gastroenterol 2017;11:559-563 } \\
\hline & $\begin{array}{l}\text { DOI: 10.1159/000479312 } \\
\text { Publisnea onine: september 26, } 2017\end{array}$ & $\begin{array}{l}\text { (C) } 2017 \text { The Author(s) } \\
\text { Published by S. Karger AG, Basel } \\
\text { www.karger.com/crg }\end{array}$ \\
\hline & \multicolumn{2}{|c|}{$\begin{array}{l}\text { This article is licensed under the Creative Commons Attribution-NonCommercial } 4.0 \\
\text { International License (CC BY-NC) (http://www.karger.com/Services/OpenAccessLicense). } \\
\text { Usage and distribution for commercial purposes requires written permission. }\end{array}$} \\
\hline
\end{tabular}

\title{
A Case of Basaloid Squamous Cell Carcinoma of Polypoid Type in the Esophagus
}

\author{
Ki Hun Lee ${ }^{a}$ Sang Jin Lee ${ }^{a}$ Hak Soo Kim $^{a}$ Sung Eun Kim ${ }^{a}$ \\ Soo Yong $\mathrm{Choi}^{\mathrm{a}}$ Hyun Ju Lee ${ }^{\mathrm{a}}$ Suk Hun Ha${ }^{\mathrm{a}}$ Kwang Hoon Oh ${ }^{\mathrm{b}}$ \\ Dae-Woon Eom ${ }^{c}$ \\ ${ }^{a}$ Department of Internal Medicine, Gangneung Asan Hospital, Ulsan University College of \\ Medicine, Gangneung, South Korea; ${ }^{b}$ Department of Internal Medicine, Suncheon \\ Hospital, Suncheon, South Korea; 'Department of Pathology, Gangneung Asan Hospital, \\ Ulsan University College of Medicine, Gangneung, South Korea
}

\section{Keywords}

Squamous cell carcinoma · Esophagus · Polyps · Surgery

\begin{abstract}
Basaloid squamous cell carcinoma of the esophagus is very rare. Further, polypoid type of esophageal cancer is also rare. We have recently treated a case of basaloid squamous cell carcinoma which presented as a $1.3-\mathrm{cm}$ esophageal polyp. A 48-year-old woman was referred to our hospital because of a polypoid mass at $36 \mathrm{~cm}$ distance from the upper incisor on endoscopic examination, and the result of the biopsy was basaloid squamous cell carcinoma. The patient underwent Ivor Lewis operation with lymph node dissection. Two basaloid squamous cell carcinomas, of 1.3 and $0.4 \mathrm{~cm}$, were diagnosed in the final pathologic examination. Regular periodic follow-up showed no evidence of recurrence or metastasis in the 5month postoperative period.


Lee et al.: A Case of Basaloid Squamous Cell Carcinoma of Polypoid Type in the Esophagus

\section{Introduction}

Basaloid squamous cell carcinoma (BSCC) has been defined in the 2005 WHO Blue Book as an aggressive high-grade variant of squamous cell carcinoma composed of both basaloid and squamous components [1]. The histogenesis of this neoplasm is controversial. Its first description and the current WHO classification suggest that the tumor originates from totipotential cells in the basal layer of squamous epithelia $[1,2]$.

BSCC more commonly occurs in the nasopharynx, tongue, larynx, and trachea. However, BSCC of the esophagus is a very rare tumor, accounting for only $0.068-4.0 \%$ of carcinomas [3].

Further, polypoid carcinoma of the esophagus is also rare. Mori at al. [4] reported that only 12 cases of 500 esophageal carcinoma surgeries were identified as having polypoid type of esophageal cancer (2.4\%). Formerly, most pure intraluminal polypoid type carcinomas were histologically reported as so-called carcinosarcomas. Some of these tumors, however, exhibit other histologic types [5-7].

Here, we document a case of BSCC which presented as an esophageal polyp.

\section{Case Report}

A 48-year-old woman was admitted to our hospital due to a polypoid mass of the esophagus identified during a medical checkup in a local clinic. She had nothing special to report in her medical history. Physical examination revealed no abnormalities, and laboratory data were within normal limits.

Esophagogastroduodenoscopy (EGD) demonstrated a polypoid mass at $36 \mathrm{~cm}$ distance from the incisor in the esophagus. After spray of Lugol solution, EGD showed a 1.3-cm Lugolvoided polyp at $36 \mathrm{~cm}$ distance from the upper incisor. Additionally, a Lugol-voided flat lesion at 30-36 cm distance from the upper incisor and a Lugol-voided flat lesion at 27-29 cm distance from the upper incisor were noted (Fig. 1). The result of the biopsy suggested that it was a BSCC.

Computed tomography (CT) of the chest demonstrated neither an esophageal mass nor mediastinal/hilar lymph node enlargement. PET-CT showed no evidence of distant metastasis.

The patient underwent esophagectomy with a gastric pull-up reconstruction and cervical anastomosis through laparotomy and right thoracotomy through the 6th intercostal space. A gross examination of the resected specimen showed a polypoid mass $(1.3 \times 1 \mathrm{~cm})$ presenting in the distal esophagus, $2 \mathrm{~cm}$ from the gastroesophageal junction and $7 \mathrm{~cm}$ from the proximal resection margin (Fig. 2). The cut surface of the polypoid mass was white, firm, and granular. Microscopically, the polypoid mass consisted of basaloid cells with oval to round nuclei, open pale chromatin, and scant basophilic cytoplasm (Fig. 3a). Occasionally, it showed a comedo-like necrosis structure (Fig. 3b). The tumor permanent pathology examination revealed BSCC. In addition, another BSCC was noted $0.4 \mathrm{~cm}$ apart from the polypoid mass. It extended to the lamina propria. Multiple separated dysplastic areas were noted. The excised 8 regional lymph nodes did not harbor tumor cells, and the proximal and distal resected margin presented no tumor.

The patient had an uneventful postoperative course. Because cancer stage was I, chemotherapy and radiotherapy were not necessary. Regular periodic follow-up showed no evidence of recurrence or metastasis in the 5-month postoperative period. 
Lee et al.: A Case of Basaloid Squamous Cell Carcinoma of Polypoid Type in the Esophagus

\section{Discussion}

BSCC is a distinct, unusual variant which more commonly occurs in the upper aerodigestive tract like the tongue, nasopharynx, larynx, and trachea. However, it is uncommon in the esophagus [8]. It accounts for only $0.068-4.0 \%$ of esophageal cancers. Microscopically, BSCC consists of basaloid cells with oval to round nuclei, open pale chromatin, and scant basophilic cytoplasm. It is arranged in solid or cribriform lobules with comedo-necrosis [9]. It is more common in older men, who present with dysphasia, odynophagia, and weight loss, similar to the symptoms caused by squamous cell carcinoma. Kumagai et al. [10] reported that the rates of lymphatic invasion, venous invasion, and lymph node metastasis were 56, 89 , and $67 \%$, respectively. Tumor recurrence was observed in $56 \%$ of the patients. These tumors are characterized by a higher proliferative activity and apoptotic indices as compared with typical esophageal squamous cell carcinoma. However, the survival rate of patients with other types of carcinoma does not differ significantly [11]. A consensus has not been reached concerning postoperative radiation therapy and chemotherapy regarding the sensitivity of these treatments $[12,13]$.

Polypoid type of esophageal cancer is rare. Mori at al. [4] reported that only 12 of 500 surgical cases of esophageal carcinoma (2.4\%) were of the polypoid type. The most common histologic type of polypoid esophageal carcinoma was squamous cell carcinoma, and 2 cases were diagnosed as carcinosarcoma. Eight of the 12 tumors were restricted to within the submucosal layer. The 5-year survival rate of these 12 patients was $44 \%$ and better than that of the other 488 patients $(24 \%, p<0.01)$ [4]. Sasajima et al. [14] also reported that the 5 -year survival rate was $71 \%$ for patients with the polypoid type of esophageal cancer versus $11 \%$ for the other types. The depth of tumor invasion was less compared with the other types. Because polypoid type carcinomas can be diagnosed at an early stage by symptoms like dysphasia, many cases show shallower tumor invasion than the other types, which can also result in a good prognosis.

\section{Statement of Ethics}

The authors have no ethical conflicts to disclose.

\section{Disclosure Statement}

None of the authors have any conflicts of interest to disclose.

\section{References}

1 Cardesa A, Zidar N, Ereño C: Basaloid squamous cell carcinoma; in Barnes L, Eveson JW, Reichart P, Sidrasky D (eds): Pathology and Genetics of Head and Neck Tumours. Kleihues P, Sobin LH (series eds): World Health Organization Classification of Tumours. Lyon, IARC Press, 2005, pp 124-125.

2 Wain SL, Kier R, Wollmer RT, et al: Basaloid-squamous carcinoma of the tongue, hypopharynx, and larynx: report of 10 cases. Hum Pathol 1986;17:1158-1166.

-3 Noguchi H, Naomoto Y, Haisa M, Yamatsuji T, Shigemitsu K, Shirakawa Y, et al: Two cases of superficial basaloid squamous carcinoma of the esophagus. Dis Esophagus 2003;16:342-345.

4 Mori M, Mimori K, Sadanaga N, et al: Polypoid carcinoma of the esophagus. Jpn J Cancer Res 1994;85:1131-1136. 


\section{Case Reports in \\ Gastroenterology}

\begin{tabular}{l|l}
\hline Case Rep Gastroenterol 2017;11:559-563 \\
\hline DOI: 10.1159/000479312 & $\begin{array}{l}\text { @ 2017 The Author(s). Published by S. Karger AG, Basel } \\
\text { www.karger.com/crg }\end{array}$ \\
\hline
\end{tabular}

Lee et al.: A Case of Basaloid Squamous Cell Carcinoma of Polypoid Type in the Esophagus

5 Olmsted WW, Lichstein JE, Hyams V: Polypoid epithelial malignancies of the esophagus. AJR Am J Roentgenol 1983;140:921-925.

-6 Linder J, Stein RB, Roggli VL, Vollmer RT, Croker BP, Postlethwait RW, Shelburne JD: Polypoid tumor of the esophagus. Hum Pathol 1987;18:692-700.

7 Matsusaka T, Watanabe H, Enjoji M: Pseudosarcoma and carcinosarcoma of the esophagus. Cancer 1976;37:1546-1555.

-8 Banks ER, Frierson HF, Mills SE, George E, Zarbo RJ, Swanson PE: Basaloid squamous cell carcinoma of the head and neck. A clinicopathologic and immunohistochemical study of 40 cases. Am J Surg Pathol 1992;16:939-946.

-9 Kobayashi Y, Nakanishi Y, Taniguchi H, Sekine S, Igaki H, Tachimori Y, Kato H, Matsubara H, Okazumi S, Shimoda T: Histological diversity in basaloid squamous cell carcinoma of the esophagus. Dis Esophagus 2009;22:231-238.

10 Kumagai Y, Nagata K, Ishiguro T, Haga N, Kuwabara K, Sobajima J, et al: Clinicopathologic characteristics and clinical outcomes of esophageal basaloid squamous carcinoma: experience at a single institution. Int Surg 2013;98:450-454.

11 Sarbia M, Verreet P, Bittinger F, et al: Basaloid squamous cell carcinoma of the esophagus: diagnosis and prognosis. Cancer 1997;79:1871-1878.

12 Luna MA, el Naggar A, Parichatikanond P, Weber RS, Batsakis JG: Basaloid squamous carcinoma of the upper aerodigestive tract. Clinicopathologic and DNA flow cytometric analysis. Cancer 1990;66:537542.

13 Larner JM, Malcolm RH, Mills SE, Frierson HF Jr, Banks ER, Levine PA: Radiotherapy for basaloid squamous cell carcinoma of the head and neck. Head Neck 1993;15:249-252.

14 Sasajima K, Takai A, Taniguchi Y et al: Polypoid squamous cell carcinoma of the esophagus. Cancer 1989;64:94-97.

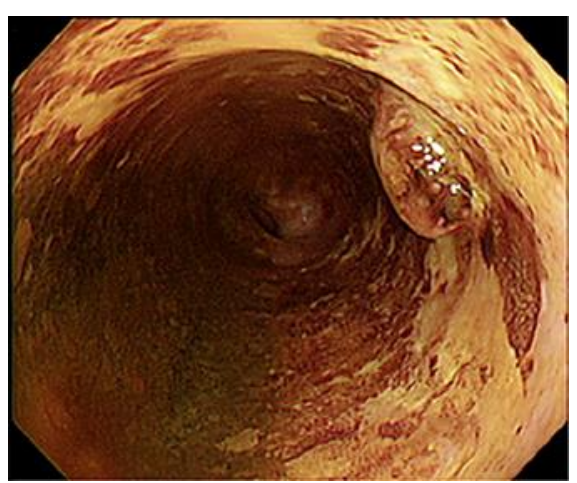

Fig. 1. The endoscopy shows a 1.3-cm Lugol-voided polyp and multiple Lugol-voided flat lesions in the lower esophagus. 

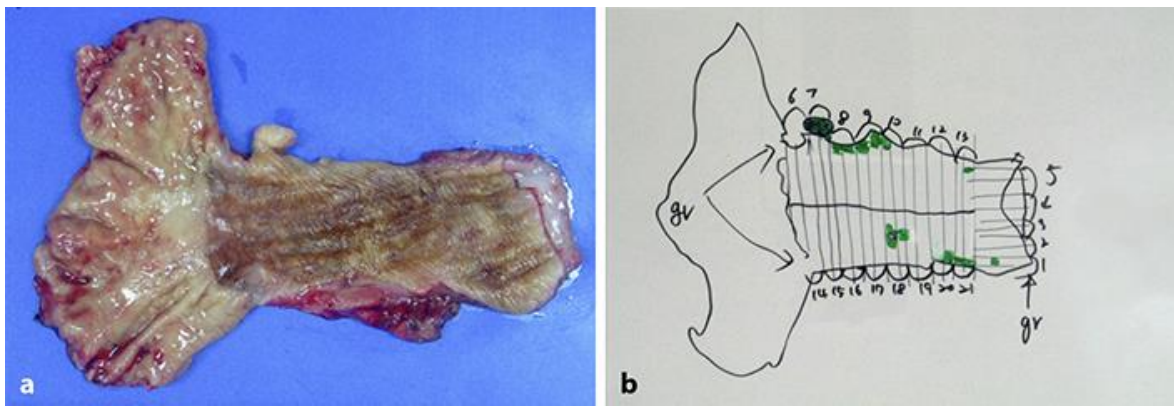

Fig. 2. The macroscopic view of the surgically resected specimen. a The macroscopic view of the surgically resected specimen shows a $1.3 \times 1 \mathrm{~cm}$ polyp at $2 \mathrm{~cm}$ distance from the gastroesophageal junction. $\mathbf{b}$ Mapping of the surgically resected specimen reveals a $1.3 \times 1 \mathrm{~cm}$ and a $0.4-\mathrm{cm}$ basaloid squamous cell carcinoma (black color). Multiple separated dysplastic areas were noted (green color).
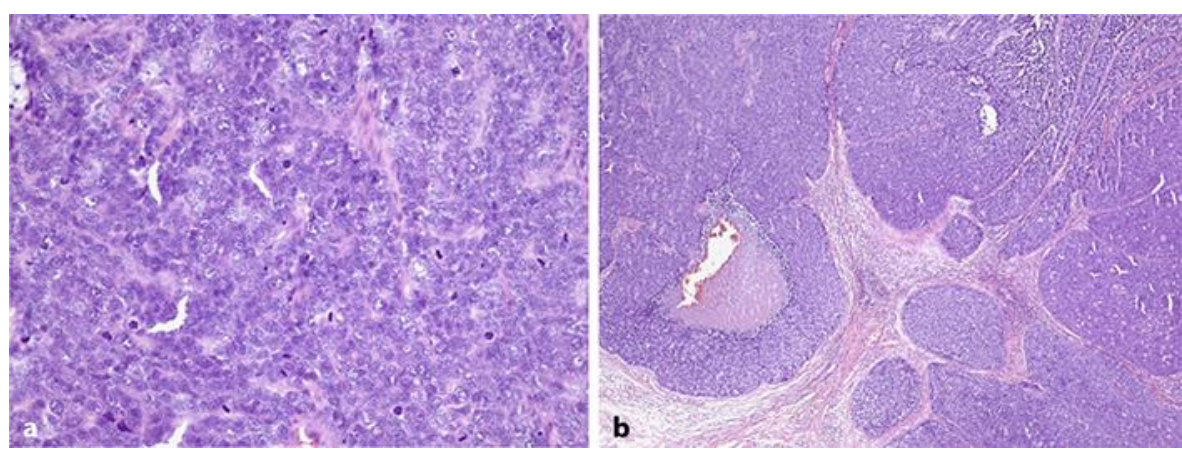

Fig. 3. Microscopic examination of the resected specimen. a The tumor consists of basaloid cells showing oval to round nuclei with open pale chromatin features. Frequent mitotic figures are also noted (HE stain, $\times 200$ ). $\mathbf{b}$ The tumor shows a solid growth pattern with a comedo-like necrosis structure (left lower portion) (HE stain, $\times 10$ ). 